\title{
Increased Susceptibility of Differentiated Mononuclear Phagocytes to Productive Infection with Human Immunodeficiency Virus-1 (HIV-1)
}

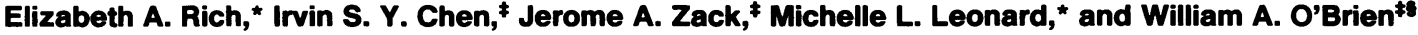 \\ ${ }^{*}$ Department of Medicine, Case Western Reserve University and University Hospitals, Cleveland, Ohio 44106; ${ }^{\ddagger}$ Departments of Medicine \\ and Microbiology and Immunology, University of California, Los Angeles School of Medicine, Los Angeles, California 90024; \\ ${ }^{\S}$ Division of Infectious Diseases, West Los Angeles Veterans Administration Medical Center, Los Angeles, California 90073
}

\begin{abstract}
Differences in susceptibility to infection of most mononuclear phagocytes with HIV-1 are not known. We investigated the relative susceptibility of autologous freshly isolated blood monocytes (MN), MN cultured in vitro to allow differentiation (CM), and alveolar macrophages (AM) from healthy subjects to productive infection with HIV-1. Cells were infected with the macrophage tropic strain HIV-1 ${ }_{\text {JR-FL }}$ and 24 gag antigen levels measured in supernatants by ELISA. Freshly isolated MN had negligible levels of p24 in supernatants. In contrast AM had peak p24 levels of $4145 \pm 1456 \mathrm{pg} / \mathrm{ml}$, mean $\pm \mathrm{SE}$, and $C M$ 9216 \pm 3118 . As a measure of entry and extent of reverse transcription, levels of viral DNA in infected mononuclear phagocytes were analyzed by quantitative polymerase chain reaction (PCR). The data using primers that amplify all transcripts including incompletely formed reverse transcripts indicated that differences in entry of the virus may contribute to differences in virus production observed with $\mathrm{MN}, \mathrm{AM}$, and $\mathrm{CM}$. Other primer pairs that detect intermediate and full-length doublestranded DNA showed that the ability to complete reverse transcription was similar among these mononuclear phagocytes. Since the lung is a major site of opportunistic infection and noninfectious complications in HIV-1-infected individuals, this increase in productive infection with HIV-1 in AM compared with $\mathrm{MN}$ could contribute to the immunopathogenesis of the lung disorders seen in the acquired immunodeficiency syndrome. (J. Clin. Invest. 1992. 89:176-183.) Key words: human immunodeficiency virus • alveolar macrophages • monocytes • reverse transcription
\end{abstract}

\section{Introduction}

HIV-1 infects blood (1-3) and tissue (4-10) mononuclear phagocytes. Because cytopathic effects of HIV-1 on mononuclear phagocytes appear to be minimal, these long-lived cells are believed to serve as major reservoirs of HIV-1 and thus are particularly important to the pathogenesis of AIDS. Alveolar

Data from parts of this paper have been presented at the American Federation of Clinical Research Meeting, November 1990 and May 1991.

Address correspondence and reprint requests to Elizabeth A. Rich, M.D., Department of Medicine, University Hospitals of Cleveland, 2074 Abington Road, Cleveland, OH 44106.

Received for publication 28 May 1991 and in revised form $14 \mathrm{Au}$ gust 1991.

J. Clin. Invest.

(C) The American Society for Clinical Investigation, Inc. 0021-9738/92/01/0176/08 \$2.00

Volume 89, January 1992, 176-183 macrophages (AM) ${ }^{1}$ are derived from blood monocytes (MN) and are considered to be the major cellular defenders of the lung against infectious agents and inhaled substances. HIV-1 infects $A M$ in vitro and in vivo $(9,10)$, but the relative susceptibility of AM and MN to productive infection with HIV-1 and the cellular determinants of infectibility are not known. Because some of the major clinical manifestations of AIDS are opportunistic infections and noninfectious complications in the lung, it is conceivable that AM are particularly susceptible to a productive infection with HIV-1.

HIV-1 is a member of the lentivirus subfamily of retroviruses certain ones of which infect mononuclear phagocytes almost exclusively (11), and infect tissue macrophages to a much greater extent than bone marrow or blood precursors of macrophages $(12,13)$. Furthermore, replication of HIV-1 in blood $\mathrm{MN}$ is increased markedly by growth and differentiation factors $(14,15)$. Monocytes cultured in vitro enlarge and differentiate to become macrophage-like and have been used as models of tissue macrophages for functional analysis and characterization of the processes of maturation and differentiation. For example, cultured monocytes (CM) are similar to AM and different from freshly isolated blood $\mathrm{MN}$ with respect to immunoregulation of $\mathrm{T}$ lymphocyte responses to stimuli and expression of the cytokines tumor necrosis factor (TNF) and IL-1 (16-18). Studies of infection of blood mononuclear phagocytes with HIV-1 often have focused on susceptibility of CM and not freshly isolated $\mathrm{MN}(1,2)$ or to freshly isolated $\mathrm{MN}$ alone (3) so that the relative susceptibility of $\mathrm{CM}$ and $\mathrm{MN}$ to infection with HIV-1 is not clear. Since CM are similar to AM in certain functions, profiles of cytokines released, and markers of differentiation, we hypothesized that their susceptibility to infection with HIV-1 might be quantitatively and qualitatively similar.

T lymphocytes do not support a productive infection with HIV-1 in vitro unless they are first stimulated with agents such as mitogens or antigens (19-21). To assess the basis for this phenomenon, we recently examined the early events of entry and reverse transcription in the life cycle of HIV-1 in T lymphocytes (22). Using a quantitative polymerase chain reaction (PCR) technique, similar levels of initiation of HIV-1 reverse transcription were demonstrated in quiescent and mitogenstimulated $\mathrm{T}$ lymphocytes indicating that entry of the virus is comparable (22). Reverse transcription, however, reached completion only in activated $\mathrm{T}$ cells. Therefore, the inability to productively infect quiescent $\mathrm{T}$ cells with HIV-1 is largely a consequence of incomplete reverse transcription.

To determine the effect of differentiation of mononuclear phagocytes on productive infection with HIV-1, we investi-

1. Abbreviations used in this paper: $\mathrm{AM}$, alveolar macrophages; $\mathrm{CM}$, cultured monocytes; $\mathrm{HI}$, heat-inactivated; $\mathrm{MN}$, freshly isolated monocytes; PCR, polymerase chain reaction. 
gated the relative susceptibility of human $\mathrm{MN}, \mathrm{AM}$, and $\mathrm{CM}$ to productive infection with HIV-1 $1_{\mathrm{JR}-\mathrm{FL}}$, a macrophage-tropic primary isolate (23). We also studied the extent of reverse transcription of HIV-1 in these cells. We found that CM and freshly isolated AM supported a productive infection with HIV-1 in vitro whereas freshly isolated $\mathrm{MN}$ did not. Reverse transcription of HIV-1 was initiated proportional to virus production in $\mathrm{MN}, \mathrm{AM}$, and in CM. Completion of reverse transcription relative to the number of reverse transcripts initiated was similar among these mononuclear phagocytes. Therefore, at least some of the differences in susceptibility of mononuclear phagocytes to productive infection with HIV-1 $1_{\mathrm{JR}-\mathrm{FL}}$ can be determined by differences in virus entry.

\section{Methods}

Preparation of cells. Subjects were healthy males $20-40 \mathrm{yr}$ of age with no known risk factors for HIV-1 infection, no history of smoking or heart or lung disease, and who were not currently taking any medications. Protocols were approved by the Investigational Review Board of University Hospitals of Cleveland, Ohio, and written consent was obtained from each subject. Venipuncture was performed to obtain 120 $\mathrm{ml}$ of whole blood that was anticoagulated with heparin $(20 \mathrm{U} / \mathrm{ml}$ of blood). Peripheral blood mononuclear cells were prepared from blood by density sedimentation on Ficoll-Hypaque (Pharmacia Fine Chemicals, Inc., Piscataway, NJ) (24). MN were prepared by adherence of mononuclear cells to serum-precoated plastic dishes for $1 \mathrm{~h}$ at $37^{\circ} \mathrm{C}$ as described previously (16). Adherent cells were removed from dishes by gently scraping with a plastic scraper and resuspended at $10^{6}$ cells $/ \mathrm{ml} \mathrm{in}$ RPMI 1640 containing penicillin $50 \mathrm{U} / \mathrm{ml}$ (Squibb-Marsam, Inc., Cherry Hill, NJ), gentamicin $5 \mu \mathrm{g} / \mathrm{ml}$ (Whittaker M.A. Bioproducts, Walkersville, MD), glutamine $2 \mathrm{mM}$ (K.C. Biologicals, Lenexa, KS) and $10 \%$ heat-inactivated FCS (Hyclone Laboratories, Logan, UT). This medium will be referred to as supplemented RPMI. By cytochemical parameters including Wright's, peroxidase, and nonspecific esterase stains of cytospin preparations, the adherent cells were 90-95\% MN. Most subjects underwent venipuncture twice so that autologous CM and MN could be infected concurrently with HIV-1.

Bronchoalveolar lavage was performed on the same subjects at the time of the second venipuncture. The nasopharynx was anesthetized with 4\% lidocaine. An Olympus BF type 4B2 flexible fiberoptic bronchoscope (Olympus Corp. of America, New Hyde Park, NY) was passed through the nose, throat, and trachea as approximately $6 \mathrm{ml}$ of $2 \%$ lidocaine was instilled. The bronchoscope was wedged into the right middle lobe and $240 \mathrm{ml}$ of $0.9 \%$ sterile saline instilled in 20 -ml aliquots into each of two segments of this lobe. Approximately $80 \%$ of the saline was retrieved. Lavage fluid was centrifuged at $400 \mathrm{~g}$ for $10 \mathrm{~min}$, and the cell pellet was suspended in supplemented RPMI and adhered to plastic identically to the method used for MN. By cytochemical stains, bronchoalveolar cells were $92-95 \%$ AM as described previously (16, 17). Both $M N$ and $A M$ were shipped overnight at room temperature from Cleveland, Ohio, to Los Angeles, California.

$\mathrm{MN}$ and $\mathrm{AM}$ then were cultured at $10^{6}$ cells $/ \mathrm{ml} \times 6 \mathrm{ml} / \mathrm{plate}$ in Iscove's medium supplemented with glutamine and penicillin (concentrations as for supplemented RPMI), streptomycin $(100 \mu \mathrm{g} / \mathrm{ml})$, and $10 \%$ heat-inactivated pooled human serum on $100 \times 20$-mm plastic petri dishes for $24 \mathrm{~h}$ at $37^{\circ} \mathrm{C}$ before infection. The purpose of the 24-h preculture of $\mathrm{MN}$ and $\mathrm{AM}$ was to allow the cells to recover from the transport and to allow time for acclimation to the petri dishes. $\mathrm{CM}$ were precultured in the same type of petri dishes for 5-7 d before infection. Contaminating and nonviable nonadherent cells were aspirated from the $\mathrm{MN}, \mathrm{AM}$, and $\mathrm{CM}$ after the period of preculture and medium containing virus was added.

$H I V-1$ infection. The viral isolate used in these experiments was

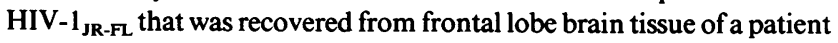
who died with severe AIDS encephalopathy (23). HIV-1 $1_{\text {JR-FL }}$ replicates efficiently in PBL and in CM $(23,25)$. Viral stocks obtained from 7-d harvests of infected PBL stored at $-70^{\circ} \mathrm{C}$ had been passaged no more than twice before use. Infections were standardized by ELISA for the p24 gag antigen of HIV-1 (Abbott Laboratories, Chicago, IL). By limiting dilution assay on PBL, approximately $30 \mathrm{pg}$ of p24 was equivalent to 1 infectious unit of HIV-1.

To eliminate HIV-1 proviral contamination present in viral stocks, virus supernatants were first filtered through a $0.22-\mu \mathrm{m}$ filter (Gelman Sciences, Inc., Ann Arbor, MI) and then treated with $1.8 \mu \mathrm{g} / \mathrm{ml}$ RNAse-free DNAse (Worthington Biochemical Corp., Freehold, NJ) plus $10 \mathrm{mM} \mathrm{MgCl}$ for $20 \mathrm{~min}$ at room temperature before cells were infected. The cells were examined using an inverted microscope before infection with HIV-1. Most of the cells were adherent with few freefloating nonviable or viable nonadherent cells (such as lymphocytes) observed. The culture medium then was removed. DNAse-treated virus or virus that had been heat inactivated (HI) at $56^{\circ} \mathrm{C}$ for $45 \mathrm{~min}$ before DNAse treatment then was added to the cells for $4 \mathrm{~h}$ at $37^{\circ} \mathrm{C}$ using a total of $3 \mathrm{ml}$ of virus stock ( $300 \mathrm{ng} \mathrm{p} 24 / \mathrm{ml}$ ) plus $10 \mu \mathrm{g} / \mathrm{ml}$ polybrene. Cells were rocked once every hour during the infection. By inspection using an inverted microscope, there were no gross differences in the appearance of the infected cells at the end of the infection period; e.g., the cells remained adherent and were not free floating. The virus-containing medium then was aspirated and the cells washed twice with PBS. To remove infected adherent cells, PBS and $0.5 \mathrm{mM}$ EDTA was added to the petri dishes for $10 \mathrm{~min}$ at room temperature and the cells then were scraped gently with a plastic scraper and mixed 1:1 with Iscove's plus $15 \% \mathrm{FCS} / 5 \%$ pooled human serum (Iscove's $15 / 5 \%$ ). Cells were pelleted by centrifugation and resuspended in supplemented Iscove's $15 / 5 \%$. Cells then were counted and viability was assessed by exclusion of trypan blue. By cytochemical parameters (Wright's, peroxidase, and nonspecific esterase stains), no lymphocytes were detectable in the $\mathrm{MN}, \mathrm{AM}$, or $\mathrm{CM}$ preparations. Cells immediately then were placed in 24-well plates at $1-5 \times 10^{5}$ cells $/ 0.5 \mathrm{ml}$ per well. Approximately 15-30 min lapsed between the end of the 4-h infection period and reseeding of cells into 24-well plates.

HIV-I detection-ELISA for p24 antigen. Supernatants of infected cells were collected every $4 \mathrm{~d}$ after infection and the medium was changed $24 \mathrm{~h}$ before each collection. Immunoassay for $\mathrm{p} 24 \mathrm{gag}$ antigen of HIV-1 was performed using an ELISA kit (Abbott Laboratories). The sensitivity level of this assay was $30 \mathrm{pg} \mathrm{p} 24 / \mathrm{ml}$.

$H I V-1$ detection-quantitative $P C R$. In order to analyze cell lysates with minimal manipulation, we used a modification of a lysis method previously described by Cetus Corp. (Berkeley, CA) (26). Adherent cells were washed with PBS and cells were lysed in $100 \mu$ l of lysis buffer (50 mM NaCl, $10 \mathrm{mM}$ Tris- $\mathrm{HCl}$ (pH-8.3), $2.5 \mathrm{mM} \mathrm{MgCl}, 0.1 \mathrm{mg} / \mathrm{ml}$ gelatin, $0.45 \%$ NP-40, $0.45 \%$ Tween 20 , and $24 \mu \mathrm{g} / \mathrm{ml}$ proteinase $\mathrm{K}$ ) for $5 \mathrm{~min}$, which was the period of time required for cells to lyse as visualized by light microscopy. The lysate was transferred to microfuge tubes and heated for $1 \mathrm{~h}$ at $56^{\circ} \mathrm{C}$ and then for $10 \mathrm{~min}$ at $95^{\circ} \mathrm{C}$ to inactivate the proteinase $\mathrm{K}$. DNA-containing lysates were frozen at $-20^{\circ} \mathrm{C}$ until use. All reagents used for PCR amplification were tested and found to be free of contaminating HIV-1 DNA.

PCR amplifications were performed as described previously (22, 27). Briefly, one of the oligonucleotide primers for each HIV-1 primer pair used was end-labeled with ${ }^{32} \mathrm{P}$ and $50 \mathrm{ng}$ used in the reactions. The second primer was not end labeled and $100 \mathrm{ng}$ was used per sample. 10 $\mu \mathrm{l}$ of test and control samples were analyzed at $50 \mathrm{mM} \mathrm{NaCl}, 25 \mathrm{mM}$

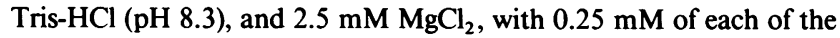
four dNTPs and 1.25 U of Taq DNA polymerase (Promega Biotec, Madison, WI) in a final volume of $25 \mu \mathrm{l}$. The reaction mixture was overlaid with mineral oil and subjected to 25 cycles of denaturation for $1 \mathrm{~min}$ at $94^{\circ} \mathrm{C}$ and annealing and extension for $2 \mathrm{~min}$ at $65^{\circ} \mathrm{C}$ using a Perkin-Elmer Cetus thermocycler. Amplified products were analyzed by electrophoresis on $6 \%$ nondenaturing polyacrylamide gels and visualized by autoradiography of dried gels.

Human $\beta$-globin-specific primers (28) and the HIV-1 specific oligonucleotide primers M667, M661, AA55, and LA45 used in PCR were described previously (22). These HIV-1-specific primers were designed 
for amplification of sequences from HIV-1 $1_{\mathrm{JR}-\mathrm{CSF}}$, and also will efficiently amplify sequences from HIV-1 $1_{\mathrm{JR}-\mathrm{FL}}$. The antisense primer BB414 (GATTGCATTACATGCACTAC) is paired with LA45 to amplify $t a t / r e v$ sequences of HIV-1 $1_{\text {JR-FL }}$. HIV-1 negative PBL DNA lysed with the same lysis buffer as test samples was used to prepare DNA standards $(30-1,000 \mathrm{ng})$. Cloned HIV- $1_{\mathrm{JR}-\mathrm{CSF}}$ DNA (pNB JR-CSF $)(29)$ was linearized with EcoR 1 that does not cleave viral sequences and was used to prepare a standard curve of HIV-1 DNA.

\section{Results}

Infection of mononuclear phagocytes with HIV-1. To determine the kinetics of virus production from mononuclear phagocytes, MN, AM, and CM were exposed to HIV-1 $1_{\mathrm{JR}-\mathrm{FL}}$ for $4 \mathrm{~h}$, washed, and supernatants collected at various times after infection. A representative of 12 experiments is shown in Fig. 1. Early p24 gag antigen levels were found to peak in supernatants of all the cell types $12 \mathrm{~d}$ after infection. Most of the cultures were terminated $12 \mathrm{~d}$ after infection. In five experiments, however, the time course was continued to $\sim 28 \mathrm{~d}$. Levels of p24 peaked at 12-16 d in supernatants of AM and CM, and began to decrease thereafter. Levels of p24 began to rise in supernatants of MN $28 \mathrm{~d}$ after infection. Although most remained lower than that of AM and CM, in one of the 28-d MN supernatants the level of p24 approximated that of CM at $12 \mathrm{~d}$ (data not shown).

The relative susceptibility of $\mathrm{MN}, \mathrm{AM}$, and $\mathrm{CM}$ to productive infection with HIV-1 at $12 \mathrm{~d}$ after infection is shown in Table I. In each experiment, HIV-1 infection was more productive in AM than autologous $\mathrm{MN}$, and in $\mathrm{CM}$ than in AM. In fact, p24 levels in supernatants of MN rarely reached detectable levels (sensitivity of the p24 ELISA was to $30 \mathrm{pg} / \mathrm{ml}$ ). Since cell density might have influenced the efficiency of infection, cells were cultured after infection with HIV-1 at densities which differed by five-fold. The cells did not, however, reach confluency at this higher density. At both densities tested, infection with HIV-1 was greater in CM than AM and not signifcant in MN (Table I).

Immediately after the 4-h infection with HIV-1, cells were washed, covered with buffer containing EDTA for $10 \mathrm{~min}$, then scraped from the plates and resuspended in medium. Viability after scraping was $>90 \%$ in $\mathrm{MN}, \mathrm{AM}$, and $\mathrm{CM}$ as assessed by exclusion of trypan blue. Cytopathic effects with

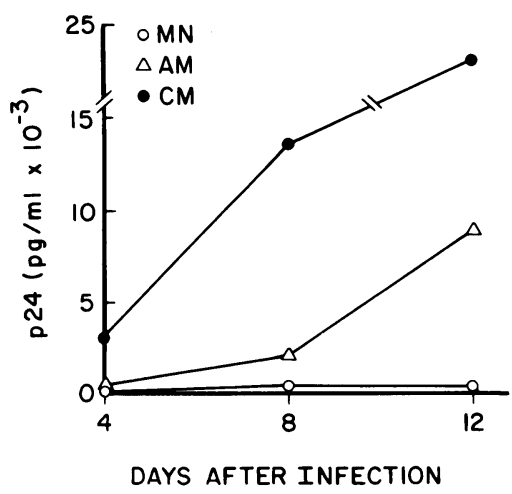

Figure 1. Kinetics of HIV-1 production from mononuclear phagocytes. MN, AM, and $\mathrm{CM}$ were infected with HIV-1 or $\mathrm{HI}$ virus as per Methods and cultured in 24 well plates at $5 \times 10^{5} /$ well in $1 \mathrm{ml}$ of supplemented Iscove's plus $15 \% \mathrm{FCS} /$ $5 \%$ pooled human serum. Supernatants were collected every $4 \mathrm{~d}$ after infection with

changing of the medium $24 \mathrm{~h}$ before harvest. The p 24 gag antigen levels in culture supernatants were determined by ELISA. The p24 levels in supernatants of cells exposed to HI virus always were undetectable. Representative of 12 experiments.
Table I. P24 Antigen Content of the Supernatants of Infected Mononuclear Phagocytes

\begin{tabular}{lcc}
\hline & \multicolumn{2}{c}{ P24, number of cells per well* } \\
\cline { 2 - 3 } Cell type & $1 \times 10^{5}(n=8)$ & $5 \times 10^{5}(n=7)$ \\
\hline $\begin{array}{l}\text { Monocytes } \\
\text { Alveolar } \\
\text { macrophages }\end{array}$ & $15 \pm 15$ & $9 \pm 6 / \mathrm{ml}$ \\
$\begin{array}{c}\text { Cultured } \\
\text { monocytes }\end{array}$ & $786 \pm 274$ & $4,145 \pm 1,456$ \\
\hline
\end{tabular}

Values are given as mean $\pm \mathrm{SE}$.

* Supernatants from HIV-1 $1_{\mathrm{JR}-\mathrm{FL}}$-infected cells were collected $12 \mathrm{~d}$ after infection and assayed for p24 antigen by ELISA. The total number of subjects tested was 12 . Both densities of cells $\left(1 \times 10^{5}\right.$ and $5 \times 10^{5}$ cells/well) were tested concurrently in three of the subjects.

giant cell formation and ballooning of cells were observed by light microscopy in AM and CM after 12-16 d. Similar effects were observed rarely in $\mathrm{MN} 20 \mathrm{~d}$ after infection. To begin to examine the basis for the increased susceptibility of AM and $\mathrm{CM}$ to productive infection with HIV-1, we studied the extent of reverse transcription of HIV-1 in these cells as compared to $\mathrm{MN}$, which did not support a productive infection with HIV-1.

Early viral DNA synthesis in mononuclear phagocytes. $\mathrm{MN}, \mathrm{AM}$, and $\mathrm{CM}$ were infected with $\mathrm{HIV}-1_{\mathrm{JR}-\mathrm{FL}}$ or with virus that was heat-inactivated (HI). Cells then were lysed $24 \mathrm{~h}$ after infection as per Methods and quantitative $\mathrm{PCR}$ was performed. To quantitate the amount of total cellular DNA in each sample, we used human $\beta$-globin-specific oligonucleotide primers (Fig. $2 A$ ).

The same volume of lysate from these cells was subjected concurrently to amplification by PCR using the R/U5 oligonucleotide primer pair M667/AA55. This primer pair amplifies the first region of the HIV-1 genome synthesized during reverse transcription and detects all viral DNA including initial reverse transcripts. This primer pair was therefore chosen to detect the total number of copies of HIV-1 initiated during reverse transcription. The R/U5 primers (M667/AA55) detected HIV-1 copies in MN lysates as well as in those of AM and CM (Fig. 2 $B$ ). MN showed approximately 100 copies $/ 4 \times 10^{3}$ cells; $A M$, 300 ; and CM, 3,000 copies. Similar results were seen in each of seven separate experiments; the results of five are shown in Table II. Thus, although there was no significant virus production after infection of $\mathrm{MN}$, entry and reverse transcription were clearly demonstrated. It remained possible that reverse transcription was initiated but was incomplete in MN.

Extent of reverse transcription in mononuclear phagocytes. To determine whether differences in susceptibility to productive infection with HIV-1 between $\mathrm{MN}$ and $\mathrm{AM}$ are associated with differences in completion of reverse transcription, we next examined the extent of reverse transcription in these cells. First, a tat/rev oligonucleotide primer pair, LA45/BB414, designed to detect an intermediate structure in reverse transcription was used during PCR. As shown in Fig. $2 C$, when this tat/rev primer pair was used the copy number of HIV-1 was $30-100$ in $\mathrm{MN} ; 100-300$ in AM and 1,000-3,000 in CM. Thus, reverse transcription extended at least to intermediate stages in all three cell types. 


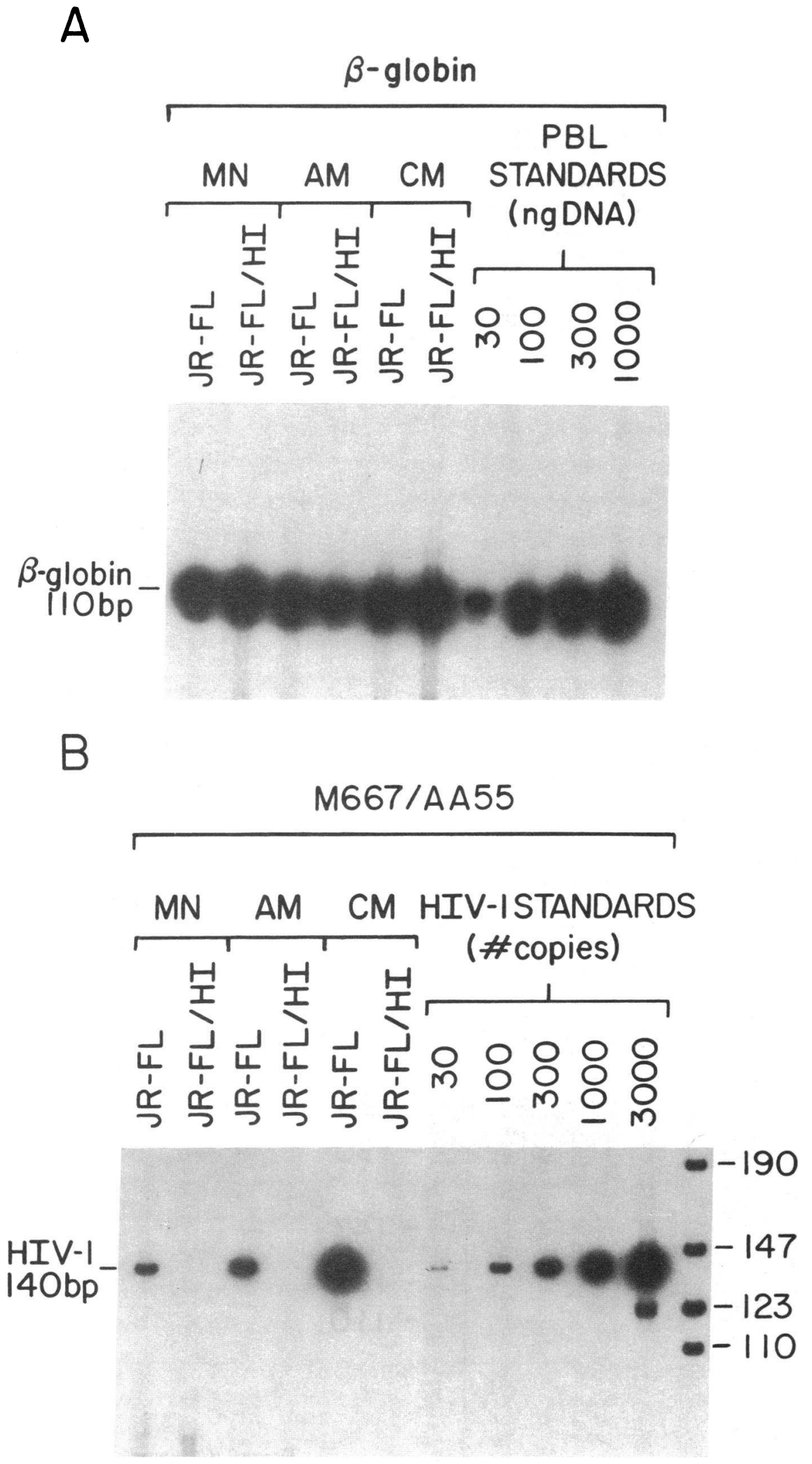

Figure 2. Quantification of cellular and HIV-1 DNA in mononuclear phagocytes infected in vitro by PCR analysis. $(A)$ Quantification of cellular DNA in HIV-1infected mononuclear phagocytes. MN, $A M$, and CM were infected with HIV- $1_{\text {JR-FL }}$ or $\mathrm{HI}$ virus using $300 \mathrm{ng} \mathrm{p} 24 / \mathrm{ml}$ plus polybrene for $4 \mathrm{~h}$, washed and transferred to 24 well plates at $2.5 \times 10^{5}$ cells/well. After 24 h culture at $37^{\circ} \mathrm{C}$, cells were lysed (Methods) and PCR performed on the equivalent of $2.5 \times 10^{4}$ cells using B-globin-specific oligonucleotide primers. Known amounts of peripheral blood lymphocyte (PBL) DNA were amplified concurrently to quantify cellular DNA levels in experimental samples and are indicated. The amplified product from the equivalent of $4 \times 10^{3}$ cells was loaded onto the gel and an autoradiogram of the amplified products is shown. (B) Quantification of initiation of reverse transcripts in infected mononuclear phagocytes. Amplification was performed as described in Fig. $2 A$ using the R/U5 oligonucleotide primer pair M667/AA55. HIV-1 standards were amplified in parallel. The molecular weight marker is pGEM digested with Hpa II and end labeled with $\left[\alpha-{ }^{32} \mathrm{P}\right]-\mathrm{aCTP}$ by Klenow. ( $C$ ) Quantification of intermediate-length reverse transcripts in infected mononuclear phagocytes. PCR analysis of the same samples as above was performed using the tat/rev oligonucleotide primer pair LA45/BB414. (D) Quantification of full-length reverse transcripts in infected mononuclear phagocytes. PCR analysis of the same samples as above was performed using the LTR/gag primer pair M667/M661.

Next, the LTR/gag oligonucleotide primer pair M667/ M661 that only will detect full or nearly complete reverse transcripts was used for PCR analysis. When this LTR/gag primer pair was used, MN showed $\sim 10$ copies of HIV-1; AM showed 100-300 copies; and CM showed between 300-1,000 copies (Fig. $2 \mathrm{D}$ ). Therefore, reverse transcription extended to full 


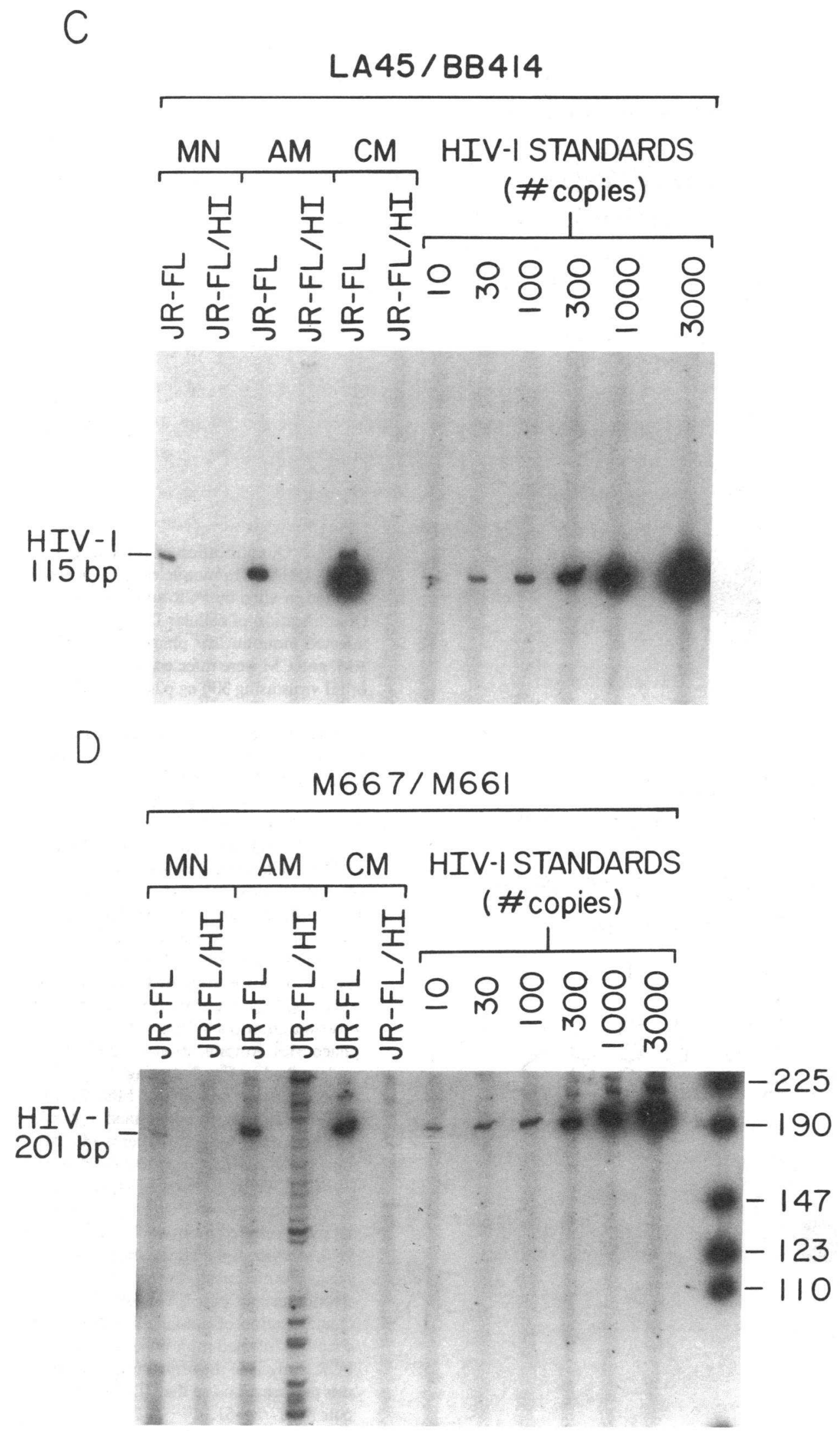

Figure 2 (Continued)

length in all of the groups of mononuclear phagocytes infected with HIV-1 in vitro but low levels in MN may not be sufficient to allow productive infection to ensue. Table II shows the PCR analysis from five experiments in which both the M667/AA55 and M667/M661 primer pairs were used. In general, more copies of full-length HIV-1 DNA were found in lysates of CM than 
$\mathrm{AM}$ or $\mathrm{MN}$; and more in $\mathrm{AM}$ than $\mathrm{MN} 24 \mathrm{~h}$ after infection. A similar pattern was seen at 6 and $48 \mathrm{~h}$ after infection $\mathrm{HIV}-\mathrm{l}_{\mathrm{JR}-\mathrm{FL}}$ (data not shown). The number of full-length reverse transcripts relative to the number initiated, however, was similar among mononuclear phagocytes; e.g., $\sim 10-30 \%$ of the number of reverse transcripts initiated reached completion, suggesting that there are not major differences in ability to reverse transcribe in these cell types. This differs from previous observations in infected quiescent $\mathrm{T}$ cells, where reverse transcription is not completed (22).

\section{Discussion}

We examined the relative susceptibility of MN, AM, and CM to productive infection with the macrophage-tropic strain HIV- $1_{\mathrm{JR}-\mathrm{FL}}$ and measured the extent of reverse transcription of HIV-1 in these cells. CM and AM from all subjects supported an early productive infection with HIV-1 beginning at $4 \mathrm{~d}$ after infection and peaking at $12 \mathrm{~d}$. CM reproducibly produced higher virus titers than AM. There was no detectable p24 viral antigen in supernatants of $\mathrm{MN}$ during the first $3 \mathrm{wk}$ after infection in any experiment. At day 28 after infection, a low level of p24 was observed in cultures of infected MN. This late rise in p24 levels in supernatants of $M N$ could be attributed to spreading of virus between cells and/or to in vitro differentiation of MN following adherence for several days in culture leading to activation and virus production.

For several reasons, it is unlikely that the observed productive infection with HIV-1 could be due to contaminating lymphocytes in these primary adherent cell cultures. All the cell types tested underwent two adherence steps. The first was for 1 $h$. The second adherence step was either for $24 \mathrm{~h}$ (MN and AM) or for 5-7 d (CM). This step further enriched for adherent cells and by cytochemical parameters (Wright's, peroxidase, and nonspecific esterase stains), all of the cells that were exposed to HIV-1 were mononuclear phagocytes. In addition, in the current experiments, no exogenous mitogenic stimulus was added (19-21) so that the observed productive infection in cultures of AM and CM was not likely to be due to contaminating lymphocytes.

The finding that productive infection of $\mathrm{AM}$ and $\mathrm{CM}$ by HIV-1 did not require further stimulation in vitro may reflect the degree of differentiation of these cells. AM differentiate in situ and also may be activated by environmental pollutants and chronically inhaled antigens. CM may be activated during the process of differentiation in vitro by adherence to plastic over a number of days or by factors in the culture medium (e.g., growth factors in the serum). The term "activation" as applied to mononuclear phagocytes generally implies, however, that the cells are primed by an immunological signal or infectious agent resulting in more efficient microbicidal activity. Thus, differentiation alone without activation as it is usually defined presumably accounts for the observed differences between $\mathrm{MN}, \mathrm{AM}$, and $\mathrm{CM}$ in susceptibility to productive infection with HIV-1. There is indeed precedence for greater susceptibility of more-differentiated mononuclear phagocytes to lentiviral infection. Tissue macrophages support the replication of the visna lentivirus of sheep to a level 1,000-fold higher than that of bone marrow precursors (11). Furthermore, both susceptibility to infection by visna virus and viral gene expression increased during in-vitro maturation of blood $\mathrm{MN}$ to macrophages (13). Growth and differentiation factors such as GMCSF and M-CSF can increase HIV-1 production in blood MN $(14,15)$ providing further evidence that the process of differentiation may lead to an increased susceptibility to infection with HIV-1.

It is believed that HIV-1 is more efficiently transmitted during coculture and that cell contact may be a major determinant of infectibility at least in vitro. Thus, transfer of virus via cell contact could confound any recognition of differences in susceptibility to infection between different cell types. Our experiments therefore were designed to avoid cell contact and rather to determine differences in infection of various mononuclear phagocytes in the absence of cell contact. None of the cell cultures including those of $\mathrm{MN}, \mathrm{AM}$, and $\mathrm{CM}$ were confluent either at the beginning or the end of the culture period; therefore, differences in confluence cannot explain our results. Cells were, of course, in closer proximity to each other at the density of $5 \times 10^{5} \mathrm{cells} /$ well but were still not confluent. Even so, more virus production was observed in $\mathrm{CM}$ and $\mathrm{AM}$ at that density and still no production of virus was observed with MN. It is possible that if cells had been confluent, our results would have been different. The effect of cell contact on susceptibility to productive infection with HIV-1 among mononuclear phagocytes is being investigated.

Gartner et al. (1) and Ho et al. (2) were the first to demonstrate that $\mathrm{MN}$ from the blood were susceptible to infection with HIV-1 in vitro. The MN were cultured for several days before infection and therefore were similar to our CM. Nicholson and colleagues showed that when freshly isolated $\mathrm{MN}$ infected in vitro with HIV-1 were added to phytohemagglutininstimulated lymphocytes, a productive infection ensued in the cell cultures but infected $\mathrm{MN}$ alone were not evaluated (3).

Table II. PCR Analysis of HIV-1 $1_{\text {JR-FL }}$ Infection of Mononuclear Phagocytes*

\begin{tabular}{|c|c|c|c|c|c|c|c|c|c|}
\hline \multirow[b]{2}{*}{ Experiment } & \multicolumn{3}{|c|}{ MN } & \multicolumn{3}{|c|}{$\mathbf{A M}$} & \multicolumn{3}{|c|}{$\mathrm{CM}$} \\
\hline & R/US & tat/rev & LTR/gag & R/U5 & tat/rev & $\mathrm{R} / \mathrm{gag}$ & R/U5 & tat/rev & LTR/gag \\
\hline 1 & 100 & 30 & 10 & 300 & $100-300$ & $100-300$ & 3,000 & 1,000 & 300 \\
\hline 2 & 100 & $\mathrm{ND}^{\ddagger}$ & 30 & 100 & ND & 100 & 3,000 & ND & 300 \\
\hline 3 & 30 & 30 & 0 & 100 & 100 & 100 & 300 & 100 & 30 \\
\hline 4 & 100 & ND & 100 & 300 & ND & 300 & ND & ND & ND \\
\hline 5 & 30 & ND & 10 & 100 & ND & 30 & 3,000 & ND & 300 \\
\hline
\end{tabular}

* Cells were lysed $24 \mathrm{~h}$ after infection with HIV- $1_{\mathrm{JR}-\mathrm{FL}}$ and PCR analysis performed. Data shown are copy numbers of HIV-1/4 $\times 10^{3}$ cell equivalents. ${ }^{\ddagger} \mathrm{ND}$, not done. 
Salahuddin et al. demonstrated that AM were infectable with HIV-1 in vitro and in vivo (10). The relative susceptibility of freshly isolated $\mathrm{MN}, \mathrm{CM}$, and tissue macrophages such as AM to infection with HIV-1, however, is not clear.

Kazazi and coworkers found higher levels of virus production after infection of $\mathrm{MN}$ with various clinical isolates of HIV1 compared to $\mathrm{MN}$ cultured in vitro from two donors (30). Our data stand in stark contrast. Strain variations affecting ability to replicate in macrophages or the limited number of subjects in whom a direct comparison of viral production of the $\mathrm{MN}$ and $\mathrm{CM}$ was made could explain the differences between this finding and ours. Olafsson et al. examined the susceptibility to infection with HIV-1 as a function of the state of differentiation of monocytes and tissue origin of macrophages (31). Peritoneal macrophages were more susceptible to infection than $\mathrm{MN}$ and $\mathrm{MN}$, more so than $\mathrm{AM}$, as measured by reverse transcriptase activity in culture supernatants. $\mathrm{MN}$ were comparable to $\mathrm{CM}$. The discrepancy between their findings and ours could be related to the viral strain used or to technical differences in manipulation of primary cells. Supernatants were collected only at 15 days after in vitro infection for CM and AM. It is conceivable that viral production already had peaked before that point for those cell types. The results of our study indicate that, like other lentiviruses, HIV-1 $1_{\text {JR-FL }}$ productively infects differentiated mononuclear phagocytes more efficiently than MN. We studied cells from 12 subjects and used a macrophage tropic strain of HIV-1 for the infections. A time course of virus replication was performed in each experiment. In no experiment could a productive infection of $\mathrm{MN}$ be demonstrated in the first 3 wk after infection. In each experiment a productive infection of both autologous $\mathrm{CM}$ and $\mathrm{AM}$ was observed during the first $12 \mathrm{~d}$ after infection with $\mathrm{CM}$ being more supportive of productive infection than AM.

Reverse transcription is required for productive infection by HIV-1. To examine the mechanism underlying the increased susceptibility to productive infection with HIV-1 in $\mathrm{CM}, \mathrm{AM}$, and $\mathrm{MN}$, reverse transcription was analyzed in these cell populations by quantitative PCR. PCR analysis of HIV-1 DNA was consistent with the p24 data in that the number of full-length reverse transcripts in $\mathrm{CM} \gg \mathrm{AM}>\mathrm{MN}$. The HIV-1 copy number in $\mathrm{MN}$ using R/U5 primers that amplify all initiated reverse transcripts was within threefold of that of AM suggesting small differences in entry of HIV-1. The 10-fold higher HIV-1 copy number in CM compared to AM or MN suggests either that entry of HIV-1 into CM exceeds that of $\mathrm{MN}$ or AM or that reverse transcription is initiated much more efficiently in these cells.

When tat/rev and LTR/gag primers were used to amplify intermediate and full-length HIV-1 DNA, respectively, the ratio of the number of copies initiated over those that completed reverse transcription was similar among the three groups of mononuclear phagocytes studied. Approximately 10-30\% of the HIV-1 DNA initiated reached completion in all the cell types. Thus, the variable susceptibility to productive infection with HIV-1 was not due to differences in the constitutive capacity to complete the process of reverse transcription. It is possible, nonetheless, that stimulation of the cells would have increased the proportion of reverse transcripts that reached completion as is seen in mitogen-stimulated lymphocytes (22).

So, what is the basis for the decreased productive infection in MN? Differences in virus entry may not account for all the differences in susceptibility between $\mathrm{MN}$, AM, and CM, partic- ularly because the total number of reverse transcripts as detected by the $\mathrm{R} / \mathrm{U} 5$ primers is detectable in $\mathrm{MN}$ and within threefold of that seen in AM. Nonetheless, increased virus production was associated with differences in levels of total viral DNA early after infection. It is possible that our results are specific to the HIV-1 strain (HIV-1 $1_{\mathrm{JR}-\mathrm{FL}}$ ) used and that other strains of HIV-1 do not productively infect mononuclear phagocytes in the same pattern as that observed for the macrophage-tropic strain used in this study. Expression of CD4 on mononuclear phagocytes also could be a determinant of a productive infection with HIV-1 by affecting virus binding. Differences in processes in viral replication that follow entry and initiation of reverse transcription also must be considered, i.e., integration of HIV-1, activation of viral gene expression, and posttranscriptional packaging of the virus particle. For example, in stimulated $\mathrm{T}$ lymphocytes and in mononuclear phagocytes the transcriptional factor NF- $\kappa$ B stimulates the HIV-1 enhancer; activation of HIV-1 gene expression is known to be induced by NF- $\kappa$ B during monocyte differentiation (32). NF$\kappa \mathrm{B}-$ binding activity is present constitutively in human $\mathrm{MN}$ and CM (32) but has not been directly compared quantitatively and is not known for human AM. The cytokines TNF and IL-1 activate this transcriptional factor (33) and human AM and CM express higher levels of TNF than do blood MN (17). Therefore, differences in production of these cytokines by mononuclear phagocytes could result in differential activation of NF- $\kappa$ B and thus, ultimately, replication of HIV-1.

The load of HIV-1 in MN from HIV-1-infected individuals as detected by polymerase chain reactions is controversial. Using gag, env, and LTR primers, Schnittman et al. found that the main reservoir for HIV-1 in human peripheral blood is a $\mathrm{T}$ lymphocyte and that $\mathrm{MN}$ from only 2 of 14 patients carried HIV-1 DNA (34). McElrath et al. recently reported that both blood lymphocytes and MN from all of the HIV-1-infected patients studied carry the virus as determined by PCR analysis (35). The burden of HIV-1 in tissue macrophages such as AM in HIV-1-infected individuals has not been delineated. Furthermore the number of initiated HIV-1 copies that complete reverse transcription in vivo in $\mathrm{MN}$ or tissue macrophages is not known. Elucidation of the basis for differences in vitro and possibly in vivo among mononuclear phagocytes in susceptibility to infection with HIV-1 clearly is vital for better understanding the organ specificity and thus the pathogenesis of AIDS.

\section{Acknowledgments}

The thoughtful and thorough critique of this manuscript by Dr. Jerrold J. Ellner is much appreciated. This work was supported by the National Institutes of Health U. S. Public Health Service grants HL-43571, HL01829, and Clinical Research Center grant M01RR00080, and the State of California University-wide AIDS Research Program.

\section{References}

1. Gartner, S., P. Markovits, D. M. Markovitz, M. H. Kaplan, R. C. Gallo, and M. Popovic. 1986. The role of mononuclear phagocytes in HTLV-III/LAV infection. Science (Wash. DC). 233:215-219.

2. Ho, D. D., T. R. Rota, and M. S. Hirsch. 1986. Infection of monocyte/ macrophages by human T lymphotropic virus type III. J. Clin. Invest. 77:17121715.

3. Nicholson, J. K. A., G. D. Cross, C. S. Callaway, and J. S. McDougal. 1986. In vitro infection of human monocytes with human $T$ lymphotropic virus type III/lymphadenopathy-associated virus (HTLV-III/LAV). J. Immunol. 137:323329. 
4. Muller, H., S. Falk, and H. J. Stutte. 1986. Accessory cells as primary target of human immunodeficiency virus HIV infection. J. Clin. Pathol. (Lond.). 39:1161.

5. Koenig, S., H. E. Gendelman, J. M. Orenstein, M. C. Dal Canto, G. H. Pezeshkpour, M. Yungbluth, F. Janotta, A. Aksamit, M. A. Martin, and A. S. Fauci. 1986. Detection of AIDS virus in macrophages in brain tissue from AIDS patients with encephalopathy. Science (Wash. DC). 233:1089-1093.

6. Wiley, C. A., R. D. Schrier, J. A. Nelson, P. W. Lampert, and M. B. A Oldstone. 1986. Cellular localization of human immunodeficiency virus infection within the brains of acquired immune deficiency syndrome patients. Proc. Natl. Acad. Sci. USA. 83:7089-7093.

7. Tschachler, E., V. Groh, M. Popovic, D. L. Mann, K. Konrad, B. Safai, L. Eron, F. diMarzo Veronese, K. Wolff, and G. Stingl. 1987. Epidermal Langerhans cells-A target for HTLV-III/LAV infection. J. Invest. Dermatol. 88:233237.

8. Armstrong, J. A., and R. Horne. 1984. Follicular dendritic cells and viruslike particles in AIDS-related lymphadenopathy. Lancet. ii:370-372.

9. Chayt, K. J., M. E. Harper, L. M. Marselle, E. B. Lewin, R. M. Rose, J. M. Oleske, L. G. Epstein, F. Wong-Staal, and R. C. Gallo. 1986. Detection of HTLVIII RNA in lungs of patients with AIDS and pulmonary involvement. JAMA (J. Am. Med. Asso.). 256:2356-2359.

10. Salahuddin, S. Z., R. M. Rose, J. E. Groopman, P. D. Markham, and R. C. Gallo. 1986. Human T lymphotropic virus type III infection of human alveolar macrophages. Blood. 68:281-284.

11. Gendelman, H. E., O. Narayan, S. Molineaux, J. E. Clements, and Z. Ghotbi. 1985. Slow, persistent replication of lentiviruses: Role of tissue macrophages and macrophage precursors in bone marrow. Proc. Natl. Acad. Sci. USA. 82:7086-7090.

12. Narayan, O., S. Kennedy-Stoskopf, D. Sheffer, D. E. Griffin, and J. E. Clements. 1983. Activation of caprine arthritis-encephalitis virus expression during maturation of monocytes to macrophages. Infect. Immun. 41:67-73.

13. Gendelman, H. E., O. Narayan, S. Kennedy-Stoskopf, P. G. E. Kennedy, Z. Ghotbi, J. E. Clements, J. Stanley, and G. Pezeshkpour. 1986. Tropism of sheep lentiviruses for monocytes: susceptibility to infection and virus gene expression increase during maturation of monocytes to macrophages. $J$. Virol. 58:67-74.

14. Gendelman, H. E. J. M. Orenstein, M. A. Martin, C. Ferrua, R. Mitra, T. Phipps, L. A. Wahl, H. C. Lane, A. S. Fauci, D. S. Burke, D. Skillman, and M. S. Meltzer. 1988. Efficient isolation and propagation of human immunodeficiency virus on recombinant colony-stimulating factor 1-treated monocytes. J. Exp. Med. 167:1428-1441.

15. Koyanagi, Y., W. A. O'Brien, J. Q. Zhao, D. W. Golde, J. C. Gasson, and I. S. Y. Chen. 1988. Cytokines alter production of HIV-1 from primary mononuclear phagocytes. Science (Wash. DC). 241:1673-1675.

16. Mayernik, D. G., A. Ul-Haq, and J. J. Rinehart. 1983. Differentiation-associated alteration in human monocyte-macrophage accessory cell function. $J$. Immunol. 130:2156-2160.

17. Rich, E. A., J. R. Panuska, R. S. Wallis, C. B. Wolf, M. L. Leonard, and J. J. Ellner. 1989. Dyscoordinate expression of tumor necrosis factor-alpha by human blood monocytes and alveolar macrophages. Am. Rev. Respir. Dis. 139:1010-1016.

18. Rich, E. A., D. J. Tweardy, H. Fujiwara, and J. J. Ellner. 1987. Spectrum of immunoregulatory functions and properties of human alveolar macrophages. Am. Rev. Respir. Dis. 136:258-265.

19. Folks, T., J. Kelly, S. Benn, A. Kinter, J. Justement, J. Gold, R. Redfield,
K. W. Sell, and A. S. Fauci. 1986. Susceptibility of normal human lymphocytes to infection with HTLV-III/LAV. J. Immunol. 136:4049-4053.

20. Zagury, D., J. Bernard, R. Leonard, R. Cheynier, M. Feldman, P. S. Sarin and R. C. Gallo. 1986. Long term cultures of HTLV-III-infected T cells: a model of cytopathology of T-cell depletion in AIDS. Science (Wash. DC). 231:850-853.

21. Zack, J. A., A. J. Cann, J. P. Lugo, and I. S. Y. Chen. 1988. HIV-1 production from infected peripheral blood T cells after HTLV-I induced mitogenic stimulation. Science (Wash. DC). 240:1026-1029.

22. Zack, J. A., S. J. Arrigo, S. R. Weitsman, A. S. Go, A. Haislip, and I. S. Y. Chen. 1990. HIV-1 entry into quiescent primary lymphocytes: molecular analysis reveals a labile, latent viral structure. Cell. 61:213-222.

23. Koyanagi, Y., S. Miles, R. T. Mitsuyasu, J. E. Merrill, H. V. Vinters, and I. S. Y. Chen. 1987. Dual infection of the central nervous system by AIDS viruses with distinct cellular tropisms. Science (Wash. DC). 236:819-822.

24. Böyum, A. 1968. Isolation of mononuclear cells and granulocytes from human blood. Scand. J. Clin. Lab. Invest. 21(Suppl):77-89.

25. O'Brien, W. A., Y. Koyanagi, A. Namazie, J.-Q. Zhao, A. Diagne, K. Idler, J. A. Zack, and I. S. Y. Chen. 1990. HIV-1 tropism for mononuclear phagocytes can be determined by regions of gp 120 outside the CD4-binding domain. Nature (Lond.). 348:69-73.

26. Higuchi, R. 1989. Rapid, efficient DNA extraction for PCR from cells or blood. In Amplifications: A Forum for PCR Users. Perkin-Elmer Cetus, Norwalk, CT. Issue 2, pp. 1 and 3 .

27. Lee, H., P. Swanson, V. S. Shorty, J. A. Zack, J. D. Rosenblatt, and I. S. Y. Chen. 1989. High rate of HTLV-II infection in seropositive IV drug abusers in New Orleans. Science (Wash. DC). 244:471-475.

28. Saiki, R. K., S. Scharf, F. Faloona, K. B. Mullis, G. T. Horn, H. A. Erlich, and N. Arnheim. 1985. Enzymatic amplification of $\beta$-globin genomic sequences and restriction site analysis for diagnosis of sickle cell anemia. Science (Wash. DC). 230:1350-1354.

29. Cann, A. J., Y. Koyanagi, and I. S. Y. Chen. 1988. High efficiency transfection of primary human lymphocytes and studies of gene expression. Oncogene. 3:123-128.

30. Kazazi, F., J.-M. Mathijs, P. Foley, and A. L. Cunningham. 1989. Variations in CD4 expression by human monocytes and macrophages and their relationship to infection with the human immunodeficiency virus. J. Gen. Virol. 70:2661-2672.

31. Olafsson, K., M. S. Smith, P. Marshburn, S. G. Carter, and S. Haskill. 1991. Variation of HIV infectibility of macrophages as a function of donor, stage of differentiation, and site of origin. J. Acquired Immune Defic. Syndr. 4:154164.

32. Griffin, G. E., K. Leung, T. M. Folks, S. Kunkel, and G. J. Nabel. 1989. Activation of HIV gene expression during monocyte differentiation by induction of NF-кB. Nature (Lond.). 339:70-73.

33. Osborn, L., S. Kunkel, and G. J. Nabel. 1989. Tumor necrosis factor $\alpha$ and interleukin 1 stimulate the human immunodeficiency virus enhancer by activation of the nuclear factor $\kappa$ B. Proc. Natl. Acad. Sci. USA. 86:2336-2340.

34. Schnittman, S. M., M. C. Psallidopoulos, H. C. Lane, L. Thompson, M. Baseler, F. Massari, C. H. Fox, N. P. Salzman, and A. S. Fauci. 1989. The reservoir for HIV-1 in human peripheral blood is a T cell that maintains expression of CD4. Science (Wash. DC). 245:305-308.

35. McElrath, M. J., R. M. Steinman, and Z. A. Cohn. 1991. Latent HIV-1 infection in enriched populations of blood monocytes and $\mathrm{T}$ cells from seropositive patients. J. Clin. Invest. 87:27-30. 